\title{
Public Policy Challenge in the Era of Covid-19 Disease Pandemic:
}

\author{
Understanding the Implication, Pattern and Community Relation of Low-Income Housing \\ Residents
}

\author{
Ahmad Sururi*, Rachmi Yulianti, Rethorika \\ Berthanilla, Budi Hasanah, Fikri Habibi \\ Department of Public Administration, Faculty of Social \\ Political and Law Sciences \\ Serang Raya University \\ Serang, Indonesia \\ *Ahmadbroer@gmail.com
}

\author{
Rahmi Mulyasih \\ Department of Communication Science, Faculty of Social \\ Political and Law Sciences \\ Serang Raya University \\ Serang, Indonesia
}

\begin{abstract}
The housing environment of low-income community and the condition of the houses as well as the absence of changes in community behaviour are some of the main dimensions which becomes factors in the transmission of the Covid-19 disease pandemic. The purpose of this study is to discuss the implication, pattern and relation of residents living in low-income housing in Indonesia in responding to the Covid-19 disease pandemic. The research was conducted in a qualitative descriptive form using semi-structured interviews as a data collection instrument. The results of the research showed that the health implications of Covid-19 disease pandemic have created a low financial determination of MBR (low-income community) housing loan payments, changes in pattern and relation of lowincome communities due to the situation and the environment which has the potential for Covid-19 disease pandemic transmission. The results of this study are expected to contribute to policy consideration for government and society. Covid-19 disease pandemic reminds us of the 'importance of synergy togetherness, interdependence and solidarity strengthening.
\end{abstract}

Keywords-low income communities, pandemic, covid-19

\section{INTRODUCTION}

The important point of the health protocol policy to prevent and reduce the transmission of Corona Virus Disease (Covid) 19 pandemic is to make homes to be the safest place for everyone. A house is the main key in suppressing the transmission of covid-19 [1] including in this case are the housing environment and houses conditions as the main dimension and a factor that greatly affects human health [2]. Some evidence shows that staying at home is the best way and this is reinforced by campaigns and slogans to stay at home in an effort to save human lives in the fight against Corona Virus Disease-19 around the world. However, some evidence also shows that the ideal conditions of a house with various environmental complexities that accompany it do not always make the house the best choice.

One of the factors contributing to a housing environment which is not ideal and contradicts the health campaign during the Corona Virus Disease-19 pandemic by making a house as a place of isolation [3] and the regulation of no flocking and physical distancing in social interactions [4] is the low income of housing residents. We therefore think that staying-at-home campaigns and flocking-banning during the pandemic are very tough challenges for MBR (Low Income Community). The direct impact that can be explained here is a decrease in the economic income of housing residents, which hinders the continuity of payment of the housing bills and a shift in social pattern and relation because flocking is one of the social assets of Indonesian who live in housing areas with very close building patterns.

Thus, it is important to study in depth what the impact, implication, and pattern of social relations of low-income housing residents during the Covid-19 pandemic, especially in the perspective of ideal public policies and in accordance with the desired expectations. The efforts of government housing policy in minimizing the impact of the pandemic by taking a case study in Indonesia, which is a developing country with the fourth population level in the world, with population of $271,000,000$, and a heterogeneous population, has made research on the challenges of public policy in the era of the Covid-19 pandemic for better understanding the implication, pattern and relation of residents living in low-income housing with various problem complexities and the situation of Covid19 Pandemic become very relevant.

Indonesia with a long history of housing that began in the 1960s until now is still facing the same problem that most people haven't had a house, it is recorded that up to 2020 the number of people who already have houses is only 82.63 
percent, it means that there are 11.4 million households which do not have houses so our initial conclusion in this study is that there is a high potential for the transmission of the Covid-19 disease pandemic. In addition, the high level of population density accompanied with a dense housing environment causes health impacts such as outbreaks or pandemics which are bad for the community.

The impact of the covid-19 disease pandemic does not only occur in Indonesia, the potential for pandemic transmission in Australia is even higher when it is seen based on census data taken previously before the pandemic that the number of homeless people was around 8,000 people and slept at night on the streets [5]. In addition, the research on the housing impacts demonstrated that poor housing can contribute to the transmission of infectious diseases, injuries, asthma symptoms, lead poisoning, and mental health problems [6] and positioning a house based on the shape and size or layout is part of the environment [1] and the Covid-19 disease pandemic has provided lessons to global community in the world about how to quarantine and isolate themselves at home [7,8]. This continues to be encouraged by various governments in the world as a collective effort and an important part of the policy pattern to prevent the transmission of the Covid-19 disease pandemic so it can be said that in general government policies in all countries have the same philosophy, which is to prevent and cure the Covid-19 disease pandemic by implementing health protocols for the community.

This study will discuss housing policies in Indonesia in response to the Covid-19 disease pandemic by analysing several indicators such as the financial determination of the payment for low-income housing to overcome the pandemic, the social interactions of residents who live in pandemic situation, and the low-income housing environment that has the potential to increase the pandemic transmission. As noted by [9] that Covid-19 disease pandemic reminds us of our 'togetherness, interdependence and solidarity' and thereby increases our capacity to maintain solidarity [9] caring during and possibly after the pandemic.

The purpose of this research is to discuss the challenges of housing policy in the era of Covid-19 disease pandemic by looking at the dimensions of implications, patterns, and relations of low-income housing residents in Indonesia in responding to Covid-19 disease pandemic as well as analysing several indicators such as financial determination of the payment of low-income housing residents, pattern and relation of communities who live there during Covid-19 disease pandemic situation.

\section{METHODS}

\section{A. Research Method}

This research used a case study approach. This research method was chosen to understand and gain an in-depth understanding of the implication, pattern, and relation of lowincome residents. This process is considered as the social construction of housing policy stakeholders in a housing ecosystem such as government, developers, and mortgage financial institutions. And this interaction cannot be explored using a survey instrument [10].

\section{B. Sampling Procedure}

The purpose of sampling is one of the most important differentiating instruments of qualitative research, and the selection of cases which are rich of information for in-depth study [11]. The selection of the location was made based on the case character assumptions [12] of the impact of Covid-19 disease pandemic to the implication, pattern and relation of low-income community. Based on this consideration, Kasemen sub-district, Serang City, Banten was chosen as a research location that represents the density level of low-income residents.

Eight respondents which consist of two people from government and six people from non-government participated in this study. Two respondents were from government elements, namely the State Civil Apparatus (ASN) $\mathrm{X}$ from Office 1, ASN Y from Office 2, while respondents from nongovernmental elements included sub-district officials, were ASN Z and five people from community A, community B and community $\mathrm{C}$, community $\mathrm{D}$ and community E. All respondents were male aged $30-55$ years.

Before selecting respondents, we carried out a licensing administration process with the Head of the Serang City Housing and Community Settlement Office, Kasemen subdistrict Office and the head of the neighbourhood (RT) where residents of low-income housing live. Next, we asked permission to conduct interviews to respondents. These processes were repeated in each interview process. The total number was eight respondents who agreed to participate in this study and the interview schedule was arranged based on the agreement and consent of the respondents.

The use of the alphabet aims to maintain the confidentiality of government, non-government institutions and respondents. The interviews were conducted in a semi-structured manner with open questions and lasted about 45 minutes. To make respondents feel comfortable, the interview process was taken place in the offices and houses of each respondent. The interview process was recorded using a tape recorder and the respondent's answers were noted to complete the interview data during the recording process. This interview was considered as an ideal method in understanding and exploring the experiences, attitudes, meanings, and actions of respondents [13] because this research was informed by the social constructivist paradigm where social reality is perceived as a social construction, then experiences, activities, and phenomena by each respondent is assumed to be a source of social reality and can only be explored in depth using an interview instrument [10]. 


\section{Data Analysis}

Data were analysed using systematic qualitative data analysis proposed by Miles et al [14]. Interviews were analysed through the process of data classification (coding data), labelling and category arrangement. In preparing the data classification process, it was based on research questions and interview transcripts. After categorizing the data, the data were coded, and a theme was arranged. The ordering of the themes is adjusted to the interview data used. These themes were then marked to be constructed and described to get the essence of what the data was trying to convey. Each theme was arranged according to each category and compared with all interview transcripts and placed in the same group.

\section{RESULTS}

Serang, a city with an area of $266.7 \mathrm{~km} 2$, is an economic area with the category of small-scale industries, restaurants, hotels, retail, finance, and hypermarkets. The residents of lowincome community housing on average work at companies located in the Serang city and Serang Regency which are engaged in garment, shoes, cement, rethreads and hotel services. During the Covid-19 disease pandemic, the rate the termination of employment (PHK) became increases, as in the table 1 below:

TABLE I. The NAME OF COMPANy AND The TerminAtion OF EMPLOYMENT AND SUSPEND

\begin{tabular}{|c|c|c|}
\hline \multirow[b]{2}{*}{$\begin{array}{l}\text { The Name of the } \\
\text { Company }\end{array}$} & \multicolumn{2}{|c|}{ Number of Employees } \\
\hline & $\begin{array}{l}\text { The termination of } \\
\text { employment (PHK) }\end{array}$ & Suspended \\
\hline Ultima Horison Ratu Hotel & & 58 \\
\hline $\begin{array}{l}\text { Ramayana Departemen } \\
\text { Store }\end{array}$ & 11 & 31 \\
\hline S Rizki Restaurant & & 26 \\
\hline Restaurant KFC dan MCD & & 2 \\
\hline 'Kerupuk' factory & & 8 \\
\hline $\begin{array}{l}\text { PT. Anugrah } \\
\text { Pangan Lestari }\end{array}$ & 2 & \\
\hline PT. Glico Indonesia & 4 & \\
\hline Blueband Giant Serang & 1 & \\
\hline PT. Nikomas & 15.985 & \\
\hline PT. PWI, 2.234 & 2.234 & \\
\hline Pisita Anyer Resort & 48 & \\
\hline Nikomas Gemilang 1 & 6.469 & \\
\hline Nikomas Gemilang 2 & 1.649 & \\
\hline
\end{tabular}

Source: Serang City and Regency Manpower Office, 202

\section{A. Determination of Housing Bills for Residents of MBR (Low} Income Community) Housing

Some respondents who live in low-income community housing in Serang Indonesia with diverse professional backgrounds stated that the Covid-19 disease pandemic condition is very unfavourable in terms of working time, decreased income, job losses and layoffs (fire). As stated by several respondents in the following interview results:

The Covid-19 disease pandemic situation forces companies to create a work-sharing system so that our work time is reduced and so does the income due to no overtime or additional time, as a result our housing payment bills must be rescheduled or temporarily postponed. (Community A, Male, 50 years old).

Next, one of the respondents who works as a private employee we met also raised a similar problem that the Covid19 disease pandemic situation causes the company to give the employees days off and only work once a week.

As a result of the Covid-19 disease pandemic, companies give employees days off and they only work once a week, this aims to prevent the transmission of Covid, this clearly reduces the salary we have to receive during the $2-3$ months so that the priority for household needs prioritizes food first, meanwhile for housing bills we still cannot pay them (Community B, Male, age 40 years).

Based on this, we conducted interviews with the Serang City Government regarding the aid policy that can be given directly in addition to the aid provided by the central government. The following is the result of an interview with one of the respondents from the government elements:

The principle of the policy in the Covid-19 disease pandemic situation is clear, the Serang City government will help, only need to be coordinated with the administrators of the neighbourhood (RT) and Hamlet (RW) in each region. The form of the aid we provide is rice, money, and basic necessities (ASN X, Male, 45 years old, Office 1).

Thus, based on the results of interviews that had been conducted, one of the implications of the problems faced by the community is a decrease of income so that it affects the determination of the housing bills payment.

The other results of the research show that besides the economic implications that cause difficulties in paying housing bills for most of the residents of low-income community housing, we find a very dominant problem; the Covid-19 disease pandemic health campaign has not been complied such as physical distancing in social interactions, in this case. patterns and social relations in the community in the era of the Covid-19 disease pandemic remain unchanged. If there is any change, it will only be carried out within certain limits as stated by a respondent from the community as follows:

Community pattern and relation tend to change even though it is a difficult thing for us, gathering activities such as gathering and meeting at mosques or conducting socialization activities with other residents which have become a habit for us, people cannot possibly follow the gathering invitation to maintain social distance from one another. (Community $\mathrm{C}$, Male, 41 years old)

The problem is that people of Serang, like most Indonesians, are people who like to gather, and it tends to occur in non-formal situations such as activities in mosques, majelis taklim (Muslims assembly) or other public spaces. The activities of gatherings for people who live in housing is a social capital to tie relation and social integration that has been 
carried out from generation to generation. Regarding this, we conducted an interview with one of the other respondents, as follows:

For us, gathering has been hereditary, so it is very difficult to get rid of it. In the era of the Covid-19 disease pandemic, we remind each other to be aware, to obey the governments advise by washing hands using soap, for example (Community D, male, 52 years old)

Thus, it can be ascertained that one of the causes of the potential for social interaction in the community is the condition of adjacent houses so that the patterns and social relations of the community in the era of the Covid-19 disease pandemic have not generally changed.

\section{DISCUSSION}

As emphasized in the Law of the Republic of Indonesia Number 1 of 2011 concerning housing and settlement areas, housing is a collection of houses as part of settlements, both urban and rural, which are equipped with infrastructure, facilities, and public utilities as a result of efforts to fulfil liveable houses. This confirms the view that the community's right to housing is constitutively a top priority [15]. Therefore, a participatory process in creating the capacity of housing groups to improve the quality of life together [16] can be a solution in overcoming the problem of the impact of policies on urban settlement areas in the era of the Covid-19 disease pandemic.

The results of the study had shown that the implication, pattern, and social relation of society show conflicting tendencies. There is a decline in public financial determination due to decreased income, but on the other hand, pattern and community relation in the Covid-19 disease pandemic era have not changed because they love to gather and socialize which have been a culture and habit that is difficult to break, apart from the proximity of residential buildings of low-income community. And if it is related to the challenges of housing policy, then this is one of the reasons why the success of housing policies is determined by other aspects that occur in society, so it can be said that the success of urban settlement area policies is at the level of local government needs the support of all stakeholders. In this regard, the central and local governments have an important role to play in providing housing policies and legislation that ensure citizens' rights to adequate housing and affordable housing costs for the community [17].

The results of the study show the constraints of financial determination for residents of low income communities, according to Lee [18] in this relation, that housing policy as part of economic policy related to the budget will have an influence on the performance of housing policy as a component of economic performance. The challenge then is how to link the housing system to the social security system, which for many people is the main component of social policy. Research conducted by Pawson et al [19] explains three policy implications amid the limitations of the housing industry and according to our argument it can be linked to the Covid-19 disease pandemic situation, namely First, a clear need for decent and adequate housing policies and the availability of resources based on commitments that market mechanisms will not be able to provide suitable and adequate housing for lowincome Australians. Second, the need to increase leadership from both the government, providers, and the housing industry collectively; Third, there is structuring regulation based on applicable standards.

As emphasized [20] that the problem of housing is a physical problem (density and lack of facilities and structural) and a problem of budget affordability. This includes the problem of not optimal coordination and communication between local government so that it requires commitment and harmonious cooperation between the government and the community in managing the provision of housing and settlement areas [21]. This is because the Housing policy is any action taken by the government or government agencies to influence the process or outcome of the housing sector [22]. In this case, the issue of strong and weak leadership played by the government affects the implications of urban settlement area policies.

The research description shows that the existing conditions of pattern and community relation have changed within certain boundaries, this is due to various factors such as housing management and urban settlement areas in Serang which are still slum such as the condition of housing infrastructure, access to clean water services and access to residential areas are still very limited. Therefore, encouraging the housing model and residential areas for low-income people in Malaysia through the principle of smart growth [23], the model and management of low-cost housing and residential areas by providing various services such as conference facilities, playgrounds, clinics, green open spaces with the aim to improve the quality of people's lives. This is stated by Goebe [24] that the top priorities for the public are health and work. In the health sector, basic sanitation needs are the main thing, and the fields of work are economic access and opportunities, opportunities to get training and education in creating jobs. In line with this, according to Seo [25] the first priority of housing policy in South Korea is to create a stabilizing economy and a sustainable future. Thus, the profit-oriented approach to housing must be transformed into a more socially acceptable policy that treats housing as an important social need for all members of society, and not as a tool of economic growth fraught with uncertainty.

The position of the State or government in overcoming the problems and challenges of housing policy for residents of low-income communities can be done by collaborating, utilizing resources, and having a correct understanding of the needs of local communities, it is important to start overcoming housing policy challenges [26] as well as structural analysis factors [27] that influence policy. In a different context, handling housing policies needs to pay attention to social and economic aspects, potential location, accessibility, cultural background, sustainable area management and psychological 
and social aspects [28,29]. These aspects aim to make the degree of change to be achieved both the scale of achievement desired and the target size of the policy program. Therefore, Fopp [30] emphasized that the problem of low-income housing should be seen from the perspective of construction and community social dynamics.

We suggest that even with limited conditions, various housing policies for residents of low-income communities must be able to create social, economic, and environmental impacts that provide a sense of comfort for the community. As emphasized that there are two approaches in the policy formulation process, the policy which has a direct impact on the direct interests of the majority of the community and the responsibility for the housing policy [31]. Thus, in order to provide preliminary conclusions regarding the implication, pattern and relation of housing policies for low-income residents, first the importance of encouraging the Serang Government to implement policy priorities for the very urgent needs of the community; secondly, to encourage strengthening of leadership at the local / regional level as an effort to increase the capacity of public sector organizations, especially in the strategic decision-making process; thirdly, structuring or revitalizing regulations according to regional policy standards, especially in the formulation of programs and policies for urban settlement areas.

\section{CONCLUSIONS}

Implication, pattern and relation in the framework of housing policy challenges for residents of low-income communities in Serang during the Covid-19 disease pandemic are dynamic due to various situations and accompanying factors such as low financial determination of MBR (low income community) housing loan payments, changes in pattern and community relation of residents with low income due to the situation and the environment that has the potential for the transmission of the Covid-19 disease pandemic. Thus we provide recommendations, first the importance of encouraging the City Government of Serang to implement policies for residents of low-income community housing which based on a priority scale that has been planned for community needs; secondly, to encourage strengthening of leadership at the local / regional level as an effort to increase policy capacity, especially in the era of the Covid-19 disease pandemic in the process of making strategic decisions; thirdly, revitalizing regulations in accordance with local policy standards, especially in the formulation of programs and policies for residents of low-income housing.

\section{RESEARCH CONTRIBUTION}

This research has contributed to theory and practice as follows:

- By analysing the implication, pattern and relation of residents of low-income community housing, this study contributes to the development of the theory of the impact of urban settlement area policies, especially in the perspective of exploring and discussing the implications of the welfare state and the wider housing and urban settlement area policies [32] and research on the impact of settlement area policies on low-income communities [33] and housing policy theory [22]

- By analysing the implication, pattern and resident's relation for low-income communities, this research can contribute to encouraging local governments to formulate policies based on the priority scale of public needs.

\section{RESEARCH LIMITATIONS}

This study has limitations in term of a single instrument for data collection and limited variables for exploring housing policy dynamic. Referring to this, future research will focus on these aspects by using case studies or policy evaluation approaches to explore problems in depth. Research by applying to more diverse aspects of the instrument for data collection is important as research strengthening so that the data analysis process and research objectives from multiple perspectives can be achieved.

\section{REFERENCES}

[1] M. Garber, Homes Actually Need to Be Practical Now. The Atlantic, 2020.

[2] X. Bonnefoy, "Inadequate housing and health: An overview," Int. J. Environ. Pollut., vol. 30, no. 3-4, pp. 411-429, 2007.

[3] E. Madarcos, Opinion: In world's megacities, understanding housing is key to fighting COVID-19 [Online]. Retrieved from: https://www.devex.com/news/opinion-in-world-s-megacitiesunderstanding-housing-is-key-to-fighting-covid-19-97027, 2020.

[4] D. Rogers and E. Power, "Housing policy and the COVID-19 pandemic: the importance of housing research during this health emergency," Int. J. Hous. Policy, vol. 20, no. 2, pp. 177-183, 2020.

[5] H. Pawson and P. Mares, Coronavirus lays bare 5 big housing system flaws to be fixed. Sidney: UNSW Sidney, 2020.

[6] S.C. Saegert, S. Klitzman, N. Freudenberg, J. Cooperman-Mroczek an S. Nassar, "Healthy Housing: A Structured Review of Published Evaluations of US Interventions to Improve Health by Modifying Housing in the United States, 1990-2001," Am. J. Public Health, vol. 93 no. 9, pp. 1471-1477, 2003.

[7] X. Ren, "The quarantine of a megacity: China's struggle over the coronavirus epidemic," International Journal of Urban and Regional Research, 2020

[8] M. Hang, "Preparing cities for epidemics: Lessons from the COVID19 outbreak," The Urban Now: International Journal of Urban and Regional Research, 2020

[9] J.L. Nancy, "Allegories of Contagion: on (New) Fascism, Democracy, and COVID-19," European Researc Council, 2020

[10] S.B. Merriam and E.J. Tisdell, Qualitative research: A guide to design and implementation. John Wiley \& Sons, 2015

[11] M.Q. Patton, “Two Decades of Developments in Qualitative Inquiry: A Personal, Experiential Perspective," Qual. Soc. Work, vol. 1, no. 3, pp. 261-283, 2002.

[12] R.K. Yin, Case Study Research: design and methods. Fifth Edit. London: SAGE Publications Inc., 2014. 
[13] W.G. Tierney, "Utilizing Ethnographic Interviews to Enhance Academic Decision Making," New directions for institutional research, vol. 18, no. (4), pp. 7-22, 1991.

[14] M.B. Miles and A.M. Huberman, Qualitative data analysis: An expanded sourcebook. Sage, 1994.

[15] C. Dawkins, "The right to housing in an ownership society," Housing and Society, vol. 47, no. (2), pp. 81-102, 2020.

[16] M.L. Ruiu, "Participatory processes in designing cohousing communities: the case of the community project," Hous. Soc., vol. 43, no. (3), pp. 168-181, 2016.

[17] UN, Policy Paper 10: Housing policies. New York: United Nations Conference on Housing and Sustainable Urban Development, 2017.

[18] J. Lee, "Developmentalism, social welfare and state capacity in East Asia : integrating housing and social security in Singapore," J. Asian Public Policy, vol. 2, no. 2, pp. 157-170, 2009.

[19] H. Pawson, V. Miligan and C. Martin, "Building Australia's affordable housing industry: capacity challenges and capacity-enhancing strategies strategies,” Int. J. Hous. Policy, vol. 12472018.

[20] G.T. Kingsley, Trends in housing problems and federal housing assistance. Washington, DC: Urban Institute, 2017.

[21] F.C. Sulaiman, R. Hasan and E.R. Jamaluddin, "Users Perception of Public Low Income Housing Management in Kuala Lumpur," Procedia Social and Behavioral Sciences, vol. 234, pp. 326-335, 2016.

[22] D. Clapham, "Housing theory, housing research and housing policy," Housing, Theory and Society, vol. 35, no. (2), pp. 163-177, 2018.

[23] B. Bakhtyar, A. Zaharim, K. Sopian, O. Saadatian and J. Abdulateef, "Affordable quality housing for urban low income earners in Malaysia," Available at SSRN 2184629, 2012.

[24] A. Goebel, "Sustainable urban development? Low-cost housing challenges in South Africa," Habitat Int., vol. 31, pp. 291-302, 2007.
[25] J.K. Seo, "Housing policy and urban sustainable development: evaluating the process of high-rise apartment development in Korea," Urban Policy and research, vol. 34, no. (4), pp. 330-342, 2016.

[26] C. Thompson, "Solving housing challenges: examples from a rural nonprofit housing agency," Housing and society, vol. 41, no. (2), pp. 337 342, 2014.

[27] Y. Heo, "The Development of Housing Policy in Singapore and the Sources of Path Dependence," Housing, Theory Soc., vol. 31, no. (4), pp. 429-446, 2014.

[28] B.C. Abdullahi, W.N.A. Wan Abd Aziz, A.A. Abdullah, A.M. Beksin, A. Mohammed Alashwal and R. Deraman, "Sustainable housing policy and low-income group housing: the Malaysian Experience," Australian Journal of Basic and Applied Sciences, vol. 5, no. (6), pp. 1-11, 2011.

[29] J.B. Emmanuel, "Housing Quality" To the Low Income Housing Producers in Ogbere, Ibadan, Nigeria," Procedia-Social and Behavioral Sciences, vol. 35, pp. 483-494, 2012.

[30] R. Fopp, "Social Constructionism and Housing Studies: A Critical Reflection," Urban Policy Res., vol. 26, no. (2), pp. 159-175, 2008.

[31] R.L.H. Chiu, "The Transferability of Hong Kong ' s Public Housing Policy 1," Transf. of Hong Kong's Public Hous. Policy, vol. 10, no. (3), pp. 301-323, 2010.

[32] B. Bengtsson, "Housing as a social right: Implications for welfare state theory," Scan. Polit. Stud., vol. 24, no. (4), pp. 255-275, 2001.

[33] V.R. Milligan, F.M. Dieleman and R. van Kempen, "Impacts of contrasting housing policies on low-income households in Australia and the Netherlands," Journal of Housing and the Built Environment, vol. 21, no. (3), pp. 237-255, 2006. 